\title{
Thiaminase properties in the fillet and liver of Tilapia zillii from Osinmo Reservoir: A comparative study
}

\author{
Raphael Emuebie Okonji ${ }^{1 *}$, Komolafe Olaniyi Olusola ${ }^{2}$, Leonard Ona Ehigie ${ }^{3}$, Popoola Micheal \\ Olaoluwa $^{2}$ and Kayode Samuel Bamitale ${ }^{4}$ \\ ${ }^{1}$ Department of Biochemistry, Obafemi Awolowo University, Ile-Ife, Nigeria. \\ ${ }^{2}$ Department of Zoology, Obafemi Awolowo University, Ile-Ife, Nigeria. \\ ${ }^{3}$ Department of Biochemistry, Ladoke Akintola University of Technology, Ogbomoso, Nigeria \\ ${ }^{4}$ Department of Medical Pharmacology and Therapeutics, Obafemi Awolowo University, Ile-Ife, Nigeria.
}

Accepted 18, April 2013

\begin{abstract}
The thiaminase enzymes were partially purified and characterized from Tilapia zillii fillet (flesh) and liver using ammonium sulphate precipitation. The enzyme showed specific activities of 5.20 and 1.17 $\mathrm{umol} / \mathrm{min} / \mathrm{mg}$ of protein respectively for $T$. zillii fillet and liver. The enzymes exhibited a maximal activity at pH 5.0 and 7.0 for the liver and fillet, respectively. The Michealis constant for thiamine as substrate for both tissues was of $0.4 \mathrm{mM}$ but $0.5 \mathrm{mM}$ and $22 \mathrm{mM}$ were obtained for aniline as substrate in the liver and fillet respectively. The optimum temperature of $T$. zillii thiaminases were 50 and $85^{\circ} \mathrm{C}$ for fillet and liver, respectively. Amino acids of fillet did not show significant effect on the enzyme activity but in the liver, the amino acids showed great inhibition with lysine showing complete inhibition of the enzyme. The thiaminase activities of fillet and liver were inhibited by divalent metal ions $\left(\mathrm{Zn}^{2+}, \mathrm{Sn}^{2+}, \mathrm{Mg}^{2+}\right.$ and $\mathrm{Hg}^{2+}$ ) but the enzyme from the liver was completely inhibited by $\mathrm{Mg}^{2+}$. The inhibitors (2Mercaptoethanol, ethylenediaminetetraacetic acid (EDTA), reduced glutathione (GSH), citrate and ascorbic acid) also showed different inhibitory effects on the enzymes from both tissues. EDTA and ascorbic acid did not inhibit the fillet thiaminase enzyme.
\end{abstract}

Key words: Tilapia zillii, liver, fillet, thiaminase, characterization, kinetic properties.

\section{INTRODUCTION}

Although the existence of thiaminase enzymes has been known for decades, the physiological role of these enzymes remains unknown. Thiaminase is produced by several species of bacteria (Fujita, 1954; Boyd and Walton, 1977; Abe et al. 1987) and is also found in the tissues of a number of marine and freshwater fish and shellfish (Hilker and Peter, 1966; Greig and Gnaedinger, 1971; Hirn and Pekkanen, 1975; Tillitt et al., 2005), zooplankton (Zajicek et al., 2005), insects (Nishimune et al., 2000) and plants (e.g., brackens Pteris aquiline: Parker and McCreg 1965).

Thiaminases have been reported to degrade thiamine by replacing the thiazole moiety with a variety of nucleophiles. Thiamine deficiency complex causes mortality and sublethal effects in Great Lakes salmonines and results from low concentrations of egg thiamine that are thought to be caused by thiaminolytic enzymes (that is, thiaminase) present in the diet (Riley and Evans, 2008). Thiamine deficiency causes disease in fish (Fisher et al., 1996; Riley and Evans, 2008), foxes Vulpes spp. (Green and Evans, 1940), minks Mustela vison (Petrova et al., 2003), cats, Felis silvestris catus (Anderson and Morrow, 1987), dogs Canis lupus familiaris(Houston and Hulland, 1988); chickens, Gallus gallus (Ishihara et al., 
1974); gulls (Bartoli et al., 1997), ruminants (Roberts and Boyd, 1974), american alligators Alligator mississippiensis (Sepulveda et al. 2004), and humans (disease termed beriberi: Fujita, 1954; Luxemburger et al., 2003). In many cases, thiamine deficiency is associated with a diet of raw fish (Ishihara et al., 1974; Vimokesant et al., 1982; Rouvinen et al., 1997), some species of which may contain thiaminase.

Fishes are highly important in the development of Nigeria both economically and healthwise as source of protein with low cholesterol level in the diets of many populace as well as an intermediate host to some parasites. In sub-Saharan Africa, fish accounts for $10 \%$ of the animal protein consumed, and $98 \%$ of this is finfish (Delgado and McKenna, 1997). The average per capita consumption of fish in Africa in 1992 was about $8 \mathrm{Kg}$ having increased from an average of $7 \mathrm{Kg}$ per annum from 1969 to 1974 (Ahmed, 1997). Approximately 40\% of fish consumed in Africa, south of the Sahara is freshwater fish as compared to the global average of $25 \%$ (Bonga, 1999).

Tilapia zillii considered a potential competitor with native fish for food and spawning areas (Molnar, 2008), is a voracious herbivore which constitutes a serious threat to native aquatic plants, and the organisms that depend on these. Osinmo reservoir is located in the South-Western region of Nigeria. The reservoir is home to diverse species of fishes with Tilapia species ranking tops. The reservoir serves to provide part of the region with inland water and fishing activities is the major occupation of the locals. Proteins, essentially the amino acids are required for foetal development and growth. In dietary protein, the amino acids are needed principally for growth, metabolism and maintenance, especially in the young ones. The high demand for fish and fish products call for studies into the nutritional status of the fish. Thiaminases are enzymes found in a few plants and the raw flesh and viscera of certain fish and shellfish (Fujita, 1954). Also, thiamine deficiency causes disease in fish and in human (Adamolekun et al., 1994; Fisher et al., 1996) and this implies that there is a substantial amount of thiaminase in fish. The present work, therefore, describes the comparative properties of thiaminases from two tissues of $T$. zillii (fillet and liver).

\section{MATERIALS AND METHODS}

Trizma-acids, Trizma-base, thiamine and EDTA, were purchased from Sigma Chemical Company, St. Louis, Mo, USA. Ascorbic acid, citrate, 2-mercaptoethanol and glutathione were purchased from Sigma Chemical Company, St. Louis, Mo, USA. The chlorides of magnesium, tin, mercury and zinc were used and purchased from Sigma Chemicals, USA. L-lysine, L-cysteine, L-serine, L-proline, and albumin (from bovine pancreas) were purchased from Sigma Chemical Company, St. Louis, Mo. USA. Dialysis tubing was also bought from Sigma Chemical Company. Ammonium sulphate (enzyme grade), aniline and hydrochloric acid were purchased from $\mathrm{BDH}$ Chemical Limited, Poole England. All other reagents were of analytical grade and were obtained from either Sigma or BDH. Ap- paratus used included, top load weighing balance (Mettler PN1210), pH meter (Mettler MP200), Cintra 101 double beam (UV/VIS ) spectrophotometer.

\section{Collection and extraction of samples}

Osinmo reservoir lies between latitude $07^{\circ} 52.8^{\prime} \mathrm{N}$ to $07^{\circ} 53.2^{\prime} \mathrm{N}$ and Longitude $04^{\circ} 21.2^{\prime} \mathrm{E}$ to $04^{\circ} 21.7^{\prime} \mathrm{E}$, Osun state, Southwestern, Nigeria. The catchment area is about $102 \mathrm{Km}^{2}$. The surface area of the reservoir is about $0.78 \mathrm{Km}^{2}$ with a mean maximum depth of 3.2 $\mathrm{m}$. Cast-net was used to collect fish samples. T. zillii fishes were stored in an ice-chest covered with ice before transporting to the laboratory where they were stored at temperature below $0^{\circ} \mathrm{C}$ until ready for use. They were identified and dissected at the Department of Zoology, Obafemi Awolowo University, lle lfe. The fillet and liver of $T$. zillii were excised with the aid of sharpened knife wrapped with aluminum foil and kept in the refrigerator until it was required. A total of $60 \mathrm{~g}$ of the $T$. zillii liver and $121 \mathrm{~g}$ of fillet were extracted. The weighed sample were then minced and homogenized with the use of blender in five volumes $(\mathrm{v} / \mathrm{w})$ of the homogenization buffer containing $0.2 \mathrm{M}$ sodium phosphate buffer, $\mathrm{pH} 6.5$. The homogenized samples were filtered using double layered cheese cloth and the filtrates were stirred and centrifuged at 4000 rpm for $30 \mathrm{~min}$. and the supernatants collected were used as the crude enzyme solution.

\section{Thiaminase assay}

Thiaminase I enzyme was measured according to the modification of Nishimune et al. (2000). Enzyme sample was incubated at $37^{\circ} \mathrm{C}$ in $0.1 \mathrm{M}$ Tris- $\mathrm{HCl}$ buffer, $\mathrm{pH} 8.0$ with $1.0 \mu \mathrm{M}$ thiamine and $0.4 \mathrm{mM}$ aniline and incubated for $30 \mathrm{~min}$. The remaining thiamine was oxidized with the addition of $1.0 \mathrm{ml}$ of $20 \% \mathrm{NaOH}$ and assayed spectrophotometrically. Absorbance was taken at $411 \mathrm{~nm}$. One unit of enzyme activity is that amount that catalyses the formation of one micromole of heteropyrithiamine in $30 \mathrm{~min}$. The protein concentration was determined by the method of Bradford (1976). Absorbance was read at $595 \mathrm{~nm}$. Protein concentration was extrapolated from a standard curve using bovine serum albumin (BSA) as standard.

\section{Ammonium sulphate precipitation}

The supernatant obtained from centrifugation was then precipitated with $70 \%(w / v)$ ammonium sulphate. This involved the dissolving of $27.132 \mathrm{~g}$ of ammonium sulphate in $60 \mathrm{ml}$ of enzyme solution and stirred over a period of $1 \mathrm{~h}$. This was allowed to stand for $18 \mathrm{~h}$ in the refrigerator. The resulting precipitate was collected by centrifugation at $4000 \mathrm{rpm}$ at $25 \mathrm{C}$ for $30 \mathrm{~min}$. The precipitated protein sample was subjected to dialysis in $5 \mathrm{mM}$ Tris buffer, $\mathrm{pH} 7.5$ for $8 \mathrm{~h}$ with hourly change of buffer. The dialysate was then centrifuged at $4000 \mathrm{rpm}$ for $30 \mathrm{~min}$. The precipitate was collected and reconstituted with small volume of buffer.

\section{Determination of kinetic parameters}

The kinetic parameters $\left(\mathrm{V}_{\max }\right.$ and $\left.K_{m}\right)$ of the enzyme were determined according to the modified method of Nishimune et al. (2000). The $K_{m}$ of thiamine and aniline was determined by varying the concentrations of thiamine between 0.1 and $3 \mathrm{mM}$ and that of aniline between 0.04 and $1.2 \mathrm{mM}$ in $0.1 \mathrm{M}$ Tris- $\mathrm{HCl}$ buffer, $\mathrm{pH} 8.0$, respectively. The kinetic parameters were determined from the double reciprocal plot of Lineweaver and Burk (1934). 
Table 1. Partial Purification profile of thiaminase activity in $T$. zillii Fillet and liver.

\begin{tabular}{lccccc}
\hline Fraction & $\begin{array}{c}\text { Total } \\
\text { protein }(\mathbf{m g})\end{array}$ & $\begin{array}{c}\text { Total } \\
\text { activity }(\boldsymbol{\mu})\end{array}$ & $\begin{array}{c}\text { Specific } \\
\text { activity }(\boldsymbol{\mu} / \mathbf{m g})\end{array}$ & $\begin{array}{c}\text { Purification } \\
\text { fold }\end{array}$ & \% Yield \\
\hline Crude fillet & 2725.3 & 1199.0 & 0.44 & 1.00 & 100.00 \\
Live & 926.00 & 776.1 & 0.84 & 1.00 & 100.00 \\
$70 \%$ ASP fillet & 1701.8 & 5371.9 & 3.16 & 7.80 & 62.40 \\
liver & 354.8 & 416.0 & 1.172 & 1.40 & 38.00 \\
\hline
\end{tabular}

ASP, Ammonium phosphate; $U=$ unit of thiaminase enzyme in $\mu \mathrm{mol} / \mathrm{ml} / \mathrm{min}$.

Table 2. Kinetic properties of Tilapia zillii fillet and liver Thiaminases.

\begin{tabular}{lcccc}
\hline \multirow{2}{*}{$\begin{array}{l}\text { Michealis } \\
\text { constant }\end{array}$} & \multicolumn{2}{c}{ Thiamine $(\mathbf{m M})$} & \multicolumn{2}{c}{ Aniline $(\mathrm{mM})$} \\
\cline { 2 - 5 } $\mathrm{K}_{\mathrm{m}}(\mathrm{mM})$ & Fillet & Liver & Fillet & Liver \\
$\mathrm{V}_{\max }(\mathrm{U})$ & 0.40 & 0.40 & 0.02 & 0.50 \\
\hline
\end{tabular}

$\mathrm{U}, \mu \mathrm{mol} / \mathrm{ml} / \mathrm{min}$.

\section{Effect of temperature on thiaminase activity}

The enzyme was assayed at different temperatures between 30 and $100^{\circ} \mathrm{C}$ to investigate the effect of temperature on the activity of the enzyme and to determine the optimum temperature of the enzyme. The assayed mixture was first incubated at the indicated temperature for 30 min before initiating reaction by the addition of an aliquot of the enzyme which had been equilibrated. The residual enzyme was then assayed routinely at $30 \mathrm{~min}$ interval.

\section{Effect of $\mathrm{pH}$ on thiaminase activity}

The effect of $\mathrm{pH}$ on thiaminase activity was studied by assaying the enzyme at different $\mathrm{pH}$ values: citrate buffer $\mathrm{pH}$ (3.0 to 6.0), Tris buffer $\mathrm{pH}(7.0$ to 8.0$)$, borate buffer $\mathrm{pH}(9.0$ to 10.0$)$. A reaction mixture of $1 \mathrm{ml}$ contained $0.4 \mathrm{ml}$ of Tris buffer, $0.2 \mathrm{ml}$ of thiamine, $0.2 \mathrm{ml}$ of aniline, $0.1 \mathrm{ml}$ of distilled water and $0.1 \mathrm{ml}$ of enzyme solution. It was incubated for thirty minutes at $37^{\circ} \mathrm{C}$ and then $1 \mathrm{ml}$ of $20 \% \mathrm{NaOH}$ was added. Absorbance was read at $411 \mathrm{~nm}$

\section{Effect of metal ions on thiaminase activity}

The effects of metal ions on the activity of thiaminase from fillet and liver of $T$. zillii were investigated using the following metal ions: $\mathrm{Mg}^{2+}, \mathrm{Sn}^{2+}, \mathrm{Hg}^{2+}$ and $\mathrm{Zn}^{2+}$ at a concentration of $10 \mu \mathrm{M}$. In a typical assay, $0.05 \mathrm{ml}$ of the metal ion was contained in the reaction mixture.

\section{Effect of amino acids on thiaminase activity}

The effects of amino acids on the activity of thiaminase were determined. The amino acids used were of L-proline, L-cysteine, L-serine and L-lysine. In a typical assay, $0.05 \mathrm{ml}$ of the amino acid was contained in the reaction mixture.

\section{Effect of inhibitors on thiaminase activity}

The effects of inhibitors on thiaminase activity were determined. $0.01 \mathrm{mM}$ of the inhibitors (ascorbate, citrate and glutathione (GSH), mercaptoethanol and ethyleneditetraacetic acid (EDTA)) were used in a typical enzyme assay. $0.05 \mathrm{ml}$ of these inhibitors was contained in the reaction mixture.

\section{RESULTS}

\section{Purification of thiaminase}

Purification of thiaminase was carried out as described in the materials and methods. The results of the purification of thiaminase using ammonium sulphate precipitation and dialysis from the fillet and liver of $T$. zillii are summarized in the purification table (Table 1).

\section{Kinetic parameters studies}

The $\mathrm{K}_{\mathrm{m}}$ and $\mathrm{V}_{\max }$ values of arginine are presented in Table 2 while Figure $1 A$ to $D$ show the Lineweaver-Burk plot of the two substrates.

\section{Effect of temperature on thiaminase activity}

The activity of thiaminase was assayed at temperatures between 30 and $100^{\circ} \mathrm{C}$ and the optimum temperature of the enzyme was found to be $85^{\circ} \mathrm{C}$ as shown in Figure $2 \mathrm{~A}$ and $\mathrm{B}$.

\section{Effect of $\mathrm{pH}$ on thiaminase activity}

The assay mixture contained buffers with different $\mathrm{pH}$ values (Figure $3 A$ and $B$ ).

\section{Effects of Inhibitors}

Tables 3 to 5 shows the different effects of metal ions, amino acids and inhibitors on fillet and liver thiaminase 

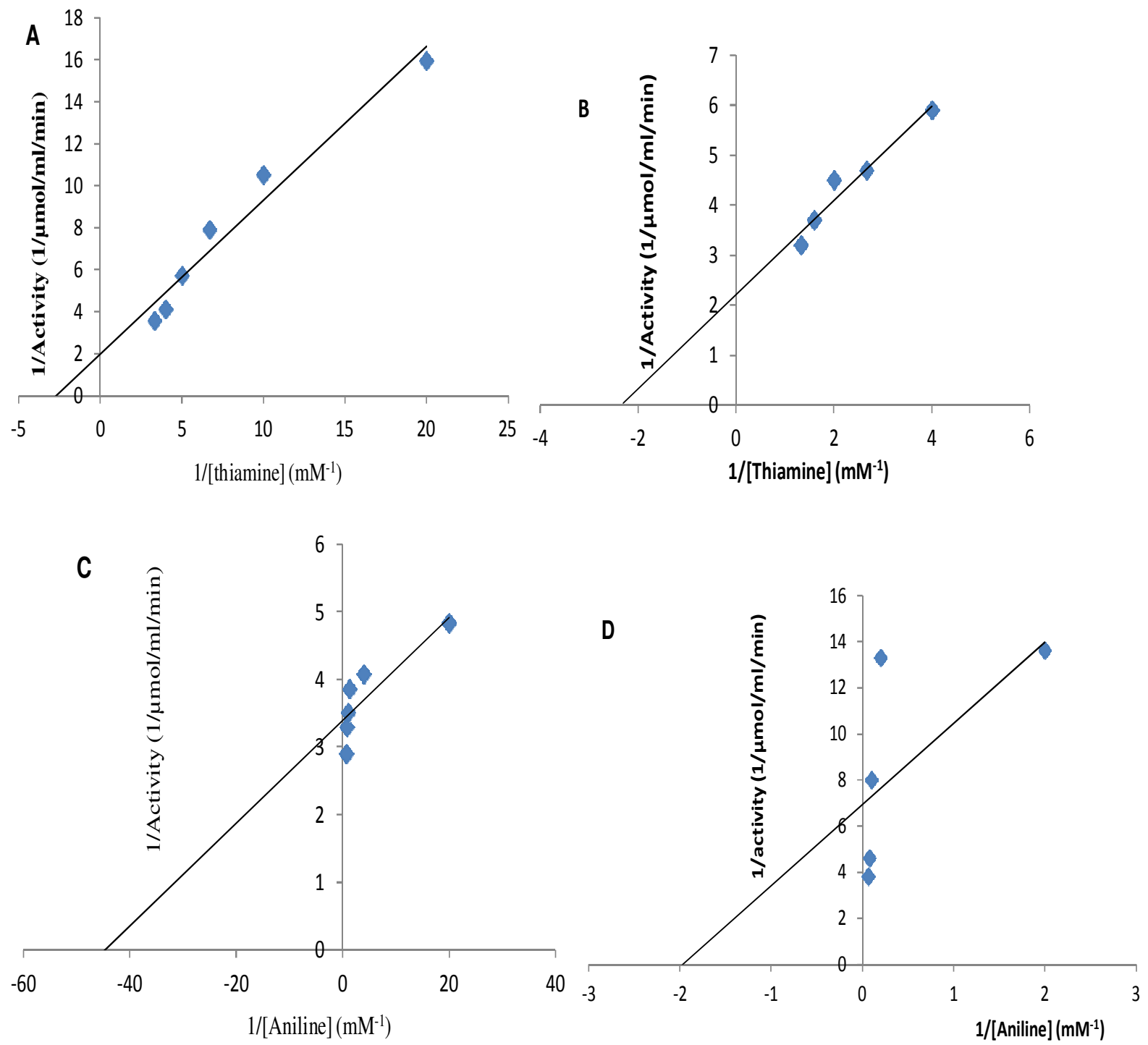

Figure 1. The Lineweaver-Burk plot showing the effect of varying concentrations of thiamine and aniline on the initial reaction velocity at $\mathrm{pH}$ 8.0. (A) Varying thiamine concentration for fillet thiaminase. (B) Varying thiamine concentration for liver thiaminase. (C) Varying aniline concentration for fillet thiaminase. (D) Varying aniline concentration for liver thiaminase.

activity expressed in percentage residual activities.

\section{DISCUSSION}

Fish and fish products provide as much as 17 to $63 \%$ protein intake of the large Nigerian populace (Abdullahi, 2001). The use of protein concentrates and fish oil in diets have been reported to reduce heart diseases, arthritis, arteriosclerosis, asthma, auto-immune disease, cancer, chronic infection, diabetes and multiple sclerosis (Cobiac et al., 1991; Gerhard et al., 1991; Adefemi, 2011).

The thiaminase activities of $T$. zillii fillet and liver tissues were partially purified using ammonium sulphate precipitation and dialysis. The specific activities of the preparations were found to be 1.172 and $5.2 \mathrm{U} / \mathrm{mg}$ of protein res- pectively. McCleary and Chick (1977) reported the thiaminase activity in Fronds of the fern nardoo (Marsilea drummondii) with a specific activity of $2.07 \mathrm{U} / \mathrm{mg}$ of protein.

The optimum temperature obtained for thiaminase in $T$. zillii fillet was $50^{\circ} \mathrm{C}$ while that for the liver thiaminase was $85^{\circ} \mathrm{C}$. The difference in the optimum temperature could be due to the difference in the internal environment/compartmentalization of the tissues. It also possible that the temperature regulating nature of the fish could account for the difference in the optimum temperatures of the enzymes since fishes are poiklothermics (Hildebrand and Goslow, 2001). A much lower optimum temperature of $37^{\circ} \mathrm{C}$ was reported for extracellular thiaminase of Bacillus thiaminolyticus (Wittliff and Airth, 1968). 
A

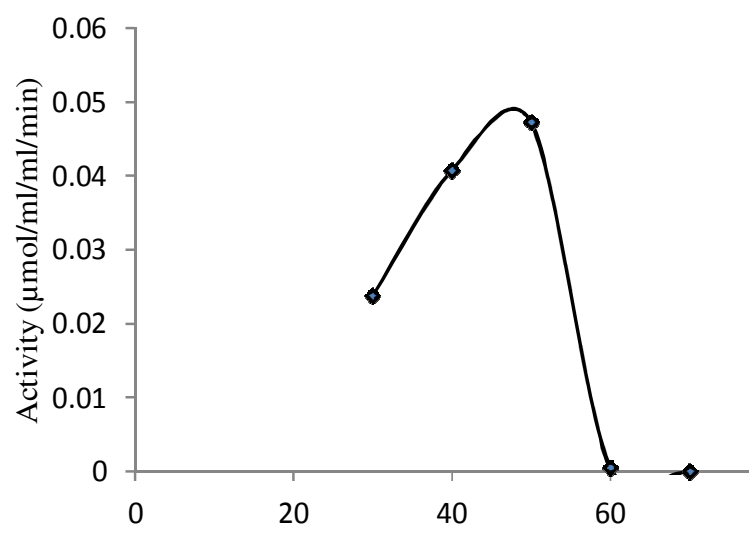

Temperature $\left({ }^{\circ} \mathrm{C}\right)$

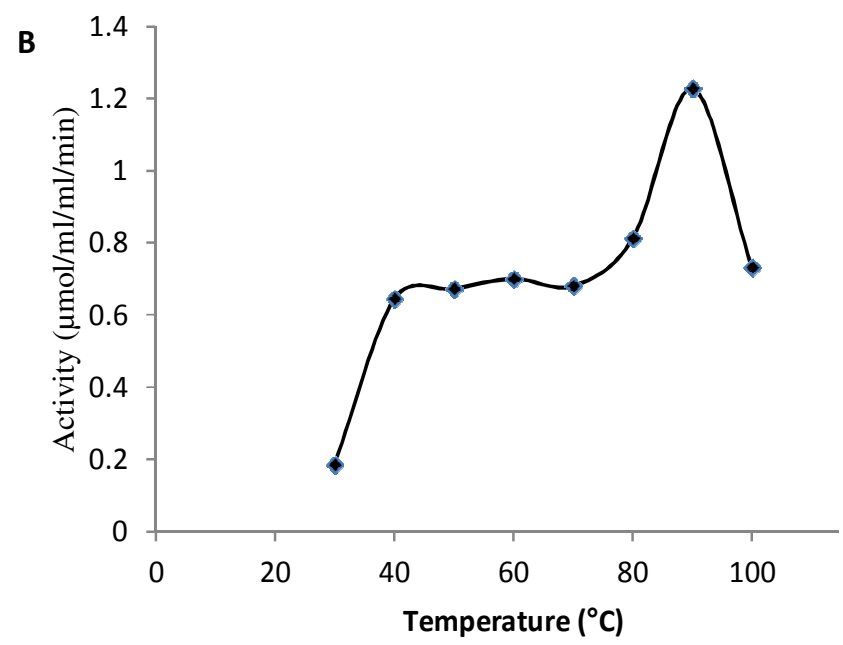

Figure 2. Effect of temperature on thiaminase activity of $T$. zillii Fillet (A) and Liver (B).

Evans (1975) reported a range of temperature optimum between 37 to $40^{\circ} \mathrm{C}$ for $B$. thiaminolyticus enzyme; shell fish and fern enzymes, 55 to $66^{\circ} \mathrm{C}$. An optimum temperature of $65^{\circ} \mathrm{C}$ was obtained for thiaminase enzyme from Marsilea drummondii, while the thiaminase in the buffer extract of Anaphe pupae was reported to have an optimal temperature of $70^{\circ} \mathrm{C}$ (Nishimune et al., 2000).

The $\mathrm{K}_{\mathrm{m}}$ values for $T$. zillii fillet in Table 2 compares very well with previous reports from other sources. Kinetic studies of thiaminase I in extracts of ruminant faeces showed that the affinity for one substrate varied with the concentration of the other substrate in the manner of a two-step transfer mechanism (Ramos et al., 2006). Other compounds have been reported to act as substrates for thiaminase; such as pyridoxine, amino acids, glutathione, taurine and 4-aminopyridine (Bos and Kozik, 2000; Nishimune et al., 2000). Thiaminase has been reported to have a wide tolerance to the nature of the nucleophile (Leinhard, 1970). Thiamine functions as a precursor of thiamine diphosphate which serves as a coenzyme in a
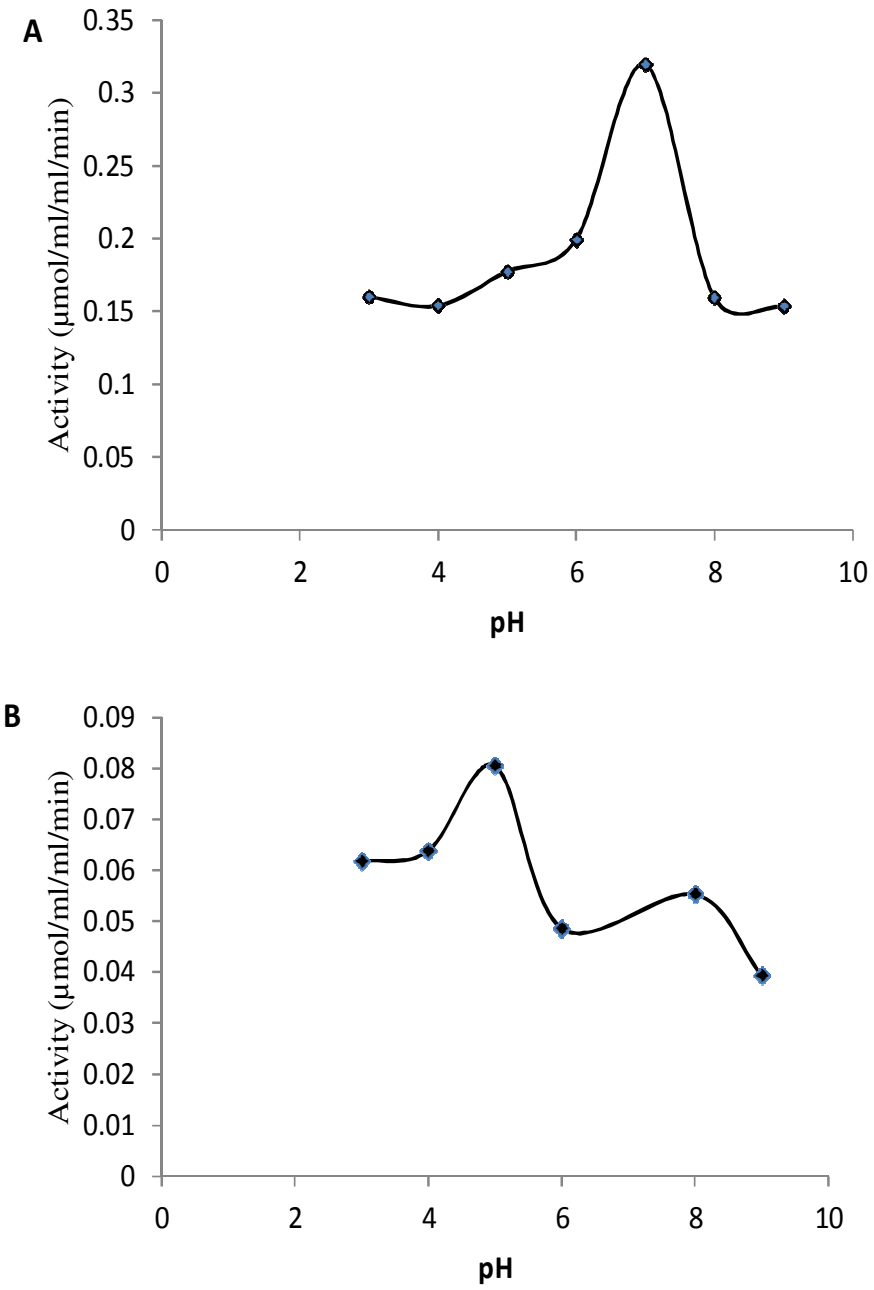

Figure 3. Effect of $\mathrm{pH}$ on thiaminase activity of $T$. zillii Fillet $(\mathrm{A})$ and Liver (B).

number of the major metabolic pathways (Friedrich, 1987). The ability of a wide range of aromatic amines, heterocyclic bases and sulphydryl compounds to participate in the hydrolysis of thiamine by thiaminase has been recognised for many years. Fujita (1954) showed that some bases were better co-substrates than others. Thiamine phosphate esters were inactive as substrates (Nishimune et al., 2000). Bos and Kozik (2000) also supported the use of numerous nucleophiles such as aniline, pyridine, and 2-mercaptoethanol by the enzyme as cosubstrates. Hanes et al. (2007) in their work on thiaminase assay in complex samples used 4-nitrothiophenolate as an alternative substrate. A wide range of heterocyclic bases, sulphydryl compounds and amines, including the non-aromatic amines 6-aminohexanoic acid and ethanolamine, act as co-substrates in the thiaminase I reaction; however, their effectiveness is dependent on both their degrees of basicity and to some extent, their stereochemistry (McCleary and Chick, 1977).

The optimum $\mathrm{pH}$ values of 5.0 and 7.0 reported for liver and fillet tissues, respectively compares very well with $\mathrm{pH}$ 
Table 3. Effect of amino acids on thiaminase activity of $T$. Zillii flesh and liver.

\begin{tabular}{lcc}
\hline \multirow{2}{*}{ Amino Acids (0.1 mM) } & \multicolumn{2}{c}{ Residual activity (\%) } \\
\cline { 2 - 3 } & Fillet & Liver \\
\hline Lysine & 92.73 & 0 \\
Serine & 97.63 & 48.05 \\
Cysteine & 83.38 & 9.87 \\
Proline & 99.11 & 6.75 \\
\hline
\end{tabular}

The enzyme was assayed in a typical enzyme assay such that the assay mixtures contain $0.1 \mathrm{ml}$ of the amino acids of $0.05 \mathrm{M}$ concentration in $1.0 \mathrm{ml}$.

Table 4. Effect of metals on thiaminase activity of $T$. zillii fillet and liver.

\begin{tabular}{lcc}
\hline \multirow{2}{*}{ Metals (0.01 $\mathbf{~ m M )}$} & \multicolumn{2}{c}{ Residual activity (\%) } \\
\cline { 2 - 3 } & Fillet & Liver \\
\hline Zinc chloride & 73.15 & 35.84 \\
Tin chloride & 42.43 & 19.48 \\
Magnesium chloride & 74.18 & 0 \\
Mercury chloride & 100 & 19.74 \\
\hline
\end{tabular}

The enzyme was assayed in a typical enzyme assay such that the assay mixtures contain $0.1 \mathrm{mM}$ of the cation concentration in 1.0 $\mathrm{ml}$.

Table 5. Effects of inhibitors on T. zillii Fillet and Liver thiaminases.

\begin{tabular}{lcc}
\hline \multirow{2}{*}{$\begin{array}{l}\text { Chelating compound } \\
\text { (0.01 } \mathbf{~ m M )}\end{array}$} & \multicolumn{2}{c}{ Residual activity (\%) } \\
\cline { 2 - 3 } 2-Mecaptoethanol & Fillet & Liver \\
EDTA & 19.59 & 59.13 \\
Glutathione & 68.04 & 48.47 \\
Citrate & 0 & 55.32 \\
Ascorbic acid & 100 & 47.56 \\
\hline
\end{tabular}

The enzyme was assayed in a typical enzyme assay such that the assay mixtures contain $1.0 \mathrm{mM}$ of 2 mercaptoethanol, $1.0 \mathrm{mM}$ of Glutathione, $0.1 \mathrm{M}$ ascorbic acid, $0.1 \mathrm{M}$ Citrate and $1.0 \mathrm{mM}$ EDTA were used in the typical reactions.

values reported for other thiaminases. An optimum $\mathrm{pH}$ of 6.8 was reported for $B$. thiaminolyticus enzyme (Wittliff and Airth, 1968). An optimum pH of 7.0 to 8.0 was reported for bracken enzyme (Evans, 1975). Similarly pH values were reported for the enzymes in Clostridium sporogenes and $B$. thiaminolyticus at 5.2 and 5.6 respectively (Boyd and Walton, 1977) using citrate-phosphate buffer. Thiaminase activity was also found to have an optimum $\mathrm{pH}$ close to 8.5 in Anaphe vernata (Nishimune et al., 2000). Thiaminases from different sources exhibits varied responses to change in $\mathrm{pH}$ and to differing activators, cosubstrates and inhibitors (Edwin et al., 1982).
Table 3 shows the results obtained for the effect of various amino acids (lysine, serine, cysteine and proline) on the activity of $T$. zillii fillet and liver thiaminases. There was very little significant effect on the enzyme activity form fillet tissue by the presence of the amino acid compared to the effect seen on the liver enzyme, where the enzyme activity was greatly inhibit with lysine and proline completely inhibiting the enzyme. The effects of amino acids may not be uncommon as reports have shown that histidine residues and carboxyl groups may be essential for thiamine binding to the active site (Bos and Kozi, 2000).

The effect of metals on the fillet thiaminase activity showed slight inhibition as compared to the inhibition of the metals on the liver enzyme (Table 4). Magnesium ion completely inhibited the liver enzyme. The different effect of the metal on the tissue enzymes could be due to the compartmentization of the enzymes in the different tissues. It is possibly to attribute the effects of metal ions on the thiaminase of the fish to the anthropogenic activities around the reservoir (Atobatele, 2008; Komolafe and Arawomo, 2008). Some of these metals have also been reported to be abundant both on land and water environment (Eisler, 1991). Studies on the assessment of heavy metals and other pollutants in the Bompai-Jakara catchment basin of which Wasai reservoir is located has shown high amount of heavy metals contamination (Mustapha, 2008; Imam, 2010). The inhibition of bacterial thiaminase enzymes by various metal ions and by primary substrates such heteropyrithiamine has been reported (McCleary and Chick, 1977).

The inhibitory compounds (2-mercaptoethanol, ethylenediamine tetraacetic acid (EDTA), glutathione, citrate and ascorbate) showed varying degree of inhibition on the $T$. zillii fillet and liver thiaminase activities. EDTA and ascorbate activated the enzyme from fillet tissue, while glutathione showed slight inhibition on both tissue enzymes. 2-mercaptoethanol and citrate showed extensive to complete inhibition on the fillet enzyme but mildly inhibited the enzyme from liver tissue.

In conclusion, this study shows that the fillet and liver of Tilapia zillii contains thiaminases that are heat-resistant. Their physicochemical properties compares very well with reported thiaminases. Literatures have revealed that thiaminases are involved in disruption of energy production pathways and effective use of acetyl CoA in the body through the inactivation of the active form of thiamine and causing reduction of cellular thiamine concentration leading to impairment of energy production. These activities, therefore makes thiaminase an anti-nutritional enzyme especially as its present in fish (a major source of essential nutrient).

\section{REFERENCES}

Abdullahi SA (2001). Investigation of Nutritional status of Chrysichthys nigrodigitatus, Bagrus filamentous and Auchenoglanis occidentalis: Family Bagridae. J. Arid Zone Fish. 39-50. 
Abe M, Ito S, Kimoto M, Hayashi R, Nishimune T (1987). Molecular studies on thiaminase I. Biochim. Biophys. Acta. 909:213-221.

Adamolekun B, Adamolekun WE, Sonibare AD, Sofowara G (1994). A doubleblind,placebo-controlled study of the efficacy of thiamin hydrochloride in a seasonal ataxia in Nigerians. Neurology 44:549551.

Adefemi OS (2011). Chemical composition of Tilapia mosambis fish from major dams in Ekiti-State, Nigeria. Afr. J. Food Sci. 5(10): 550554.

Ahmed M (1997). Fish for the poor under a rising global demand and changing fishery resources. NAGA: ICLARM Quaterly, JulyDecember. pp. 73-76.

Anderson WI, Morrow LA (1987) Thiamine deficiency encephalopathy with concurrent myocardial degeneration and polyradiculoneuropathy in a cat. Cornell Vet. 77:251-257.

Atobatele OE (2008). Physicochemical parameters, plankton, macrozoobenthos and someaspects of the biology of two species of chrisichthys (Bagridae) of Aiba reservoir, Iwo, Osun State Nigeria. (PhD Thesis.) University of Ibadan. pp. 390

Bartoli P, Bourgeay-Causse M, Combes C (1997). Parasite transmission via a vitamin supplement. BioScience 47:251-253.

Bonga $H$ (1999). Globalisation of trade relation and Africa trade for fish. Bimonthly Bullettin for the West Africa: programme on improvement for post-harvest utilization of artisanal fish catches. 45: 8-9.

Bos M, Kozik AJ (2000). Some molecular and enzymatic properties of a homogeneous preparation of thiaminase I purified from carp liver. J. Protein Chem. 19(2):75-84.

Boyd JW, Walton JR (1977). Cerebrocortical necrosis in ruminants attempt to identify source of thiaminase in affected animals. J. Comp. Path. 87:581-589.

Bradford MM (1976). A rapid and sensitive method for the quantification of microgramquantities of protein, utilizing the principle of protein dye binding. Anal. Biochem. 72, 248-254.

Cobiac L, Cliffton PM, Abbey M, Belling GB, Westel PJ (1991). Lipid, lipoprotein and lemostatic effects of fish is fish oil n-3 fatty acid is mildly perhipidenmic males. Am. J. Clin. Nutr. 53: 1210-1216

Delgado CL, McKenna AA (1997). Demand for fish in sub-Saharan Africa; NAGA: ICLARM Quaterly, July-December. pp. 79-82.

Edwin EE, Jackman R, Jones P (1982). Some properties of thiaminase associated with cerebrocortical necrosis. J. Agric. Sci. 99: 271-275.

Eisler R (1991). Cyanide hazard to fish, wildlife, and invertebrate. A synoptic review. US fish wildlife Service. Biol. Reports 85:1-23.

Evans WC (1975). Thiaminases and their effects on animals.Vit.and Horm., 33, 467-504. Intern. Biochem. Res. Rev. 2(1): 31-49, 201248

Fisher JP, Fitzsimons JD, Combs GF, Spitsbergen JM (1996). Naturally occurring thiamine deficiency causing reproductive failure in Finger Lakes Atlantic salmon and Great Lakes lake trout. Transact. Am. Fisheries Soc. 125:167-178.

Friedrich W (1987). Thiamin (Vitamin B1, aneurin). In: Handbuch der Vitamine. Munich: Urban and Schwartzenberg. 240-258.

Fujita A (1954). Thiaminase, Adv. Enzymol. Relat. Subj. Biochem. 15: 389-421.

Gerhard GT, Patton BD, Lindquist SA, Wander RC (1991). Comparison of three species of dietary fish: effects on serum concentrations of low-density lipoprotein cholesterol and apolipoprotein in normottingly ceridermic subjects. Am. J. Clin. Nutr. 4: 334-339

Green RG, Evans CA (1940). A deficiency disease of foxes. Science 92:154-155.

Greigh RA, Gnaedinger RH (1971). Occurrence of thiaminase in some common aquatic animals of the United States and Canada. NOAA Technical Report NMFS Special Scientific Report-Fisheries 631.

Hanes JW, Kraft CE, Begley TP (2007). An assay for thiaminase I in complex biological samples. Analytical Biochemistry 368: 33-38.

Hildebrand M, Goslow GE Jr. (2001). Principal ill. Viola Hildebrand. (2001). Analysis of vertebrate structure. New York: Wiley. pp. 429.

Hilker DM, Peter OF (1966). Antithiamine activity in Hawaii fish. J. Nutr. 89:419-421.

Hirn J, Pekkanen TJ (1975). Quantitative analysis of thiaminase activity in certain fish species. Nordisk Veterinaermedicin 27:646-648.

Houston DM, Hullard TJ (2007). Thiamine deficiency in a team of sled dogs. Can. Vet. J. 29: 383-385.
Imam TS (2010): Aspects of ecology and biomonitoring of heavy metals associated with industrial pollution in Bompai-Jakara catchment basin, Kano sate, Nigeria. A PhD Progress seminar paper presented at Biological Sciences Department, Bayero University Kano, 24th, February.

Ishihara T, Kinari H, Yasuda M (1974). Studies on thiaminase I in marine fish. 3. Vitamin B1 deficiency disease of chicken caused by inclusion of anchovy in diet. Bulletin of the Japanese Society of Scientific Fisheries 40:309-316.

Komolafe OO, Arawomo GAO (2008). Preliminary observations on fish species in a newly impounded Osinmo Reservoir. Turk. J. Fish. Aquat. Sci. 8: 288-292.

Leinhard G (1970). Kinetic evidence for a (4-amino-2-methyl-5pyrimidinyl) methyl enzyme intermediate in the thiaminase I reaction. Biochem. 9: 3011-3020

Lineweaver $H$, Burk $D$ (1934). The determination of enzyme dissociation constants, J. Am. Chem. Soc. 56: 658-666.

Luxemburger C, White NJ, Kuile F, Singh HM, Ailier-Frachon I, Ohn M, Chongsuphajaisiddhi T, Nosten F (2003). Beri-beri: the major cause of infant mortality inKaren refugees. Transact. Royal Soc. Trop. Med. Hyg. 97:251-255.

McCleary BV, Chick BF (1977). The purification and properties of a thiaminase I enzyme from Nardoo (Marsilea drummondii) Phytochem. 16:207-213.

Molnar J (2008). Assessing the global threat of invasive species to marine biodiversity. Frontiers Ecol. Environ. 6 (9): 485-492.

Mustapha A (2008). Environmental pollution in Kano: the contribution of wastewater discharge from kano old city and Bompai industrial estate to Jakara river basin system. J. Techno Africana 2(1): 83-88.

Nishimune T, Watanabe $Y$, Okazaki H, Akai H (2000). Thiamin is decomposed due to Anaphe spp. entomophagy in seasonal ataxia patients in Nigeria. J. Nutr. 130: 1625-1628.

Parker WH, McCreg CT (1965). Bracken (Pteris aquiline) poisoning of sheep in the North York moors. Vet. Record 77:861-865.

Petrova GG, Ilyina TN, Tyutyunnik NN, Chernikevich IP, Meldo HI (2003). Thiamine status in mink blood under alimentary hypovitaminosis $B ; 1$ after feeding thiaminase-containing fish. Science 26:106-111.

Ramos J, Marca C, Loste A, García de Jalón J, Fernández A, Cubel T (2006). Biochemical changes in apparently normal sheep from flocks affected bypolioencephalomalacia. Vet. Res. Comm. 27 (2): 111124.

Riley SC, Evans AN (2008). Phylogenetic and Ecological Characteristics associatedwith Thiaminase Activity in Laurentian Great Lakes Fishes, Transact. Am. Fisheries Soc. 137(1):147-157.

Roberts GW, Boyd JW (1974). Cerebrocortical necrosis in ruminants occurrence of thiaminase in gut of normal and affected animals and its effect on thiamine status. J. Comp. Pathol. 84:365-374.

Rouvinen KI, Anderson DM, Alward SR (1997). Effects of high dietary levels of silver hake and Atlantic herring on growing-furring performance and blood clinical-chemistry of mink (Mustela vison). Can. J. Anim. Sci. 77:509-517.

Sepulveda F, Marın SL, Carvajal J (2004). Metazoan parasites in wild fish and farmed salmon from aquaculture sites in southern Chile. Aquacult. 235: 89-100

Tillitt DE, Zajicek JL, Brown SB, Fitzsimons ZD, Honeyfield DC, Holey ME, Wright GM (2005). Thiamine and thiaminase status in forage fish of salmonines from Lake Michigan. J. Aquat. Anim. Health 17:13-25.

Vimokesant S, Kunjara S, Rungruangsak K, Nakornchai S, Panijpan B (1982). Beriberi caused by antithiamin factors in food and its prevention. Annals of the New York Academy of Sciences 378:123136.

Wittliff JL, Airth RL (1968). The extracellular thiaminase I of Bacillus thiaminolyticus I. Purification and physicochemical properties. Biochem. 7(2): 736-744

Zajicek JL, Tillitt DE, Honeyfield DC, Brown SB, Fitzsimons JD (2005). A method for measuring total thiaminase activity in fish tissues. $\mathrm{J}$. Aquat. Anim. Health 17:82-94. 